\title{
A comparative study on the user satisfaction between two different piezoelectric engines
}

\author{
Hyun-Mi Lim², ${ }^{1,2,3}$ Kyu-Bok Lee ${ }^{2,3}$, Wan-Sun Lee ${ }^{2}$, So-Young Choi ${ }^{4 *}$ \\ 'Department of Dentistry, Graduate School, Kyungpook National University, Daegu, Republic of Korea \\ ${ }^{2}$ Advanced Dental Device Development Institute, Kyungpook National University, Daegu, Republic of Korea \\ ${ }^{3}$ Department of Prosthodontics, School of Dentistry, Kyungpook National University, Daegu, Republic of Korea \\ ${ }^{4}$ Department of Oral \& Maxillofacial Surgery, School of Dentistry, Kyungpook National University, Daegu, Republic of Korea
}

Purpose: The aim of this study is to compare the performance of two piezoelectric engine systems by surveying satisfaction from dental clinicians. Materials and Methods: Two piezoelectric systems were evaluated: TRAUS XUS10 (Saeshin), PIEZOSURGERY touch (Mectron). For this study, 20 dentists responded to the 11 questionnaires in which 5 point Likert-type scale was used. The two devices were operated for 10 seconds and measured 5 times to compare the maximum noise values. In heat emission test, the handpiece was operated for 3 minutes and heat was measured at three positions each. Results: TRAUS XUS10 had higher satisfaction level on motor noise $(P<0.05)$. About function key and handpiece heat generation, PIEZOSURGERY touch showed higher satisfaction $(P<0.05)$ than TRAUS XUS10. The maximum noise level for each of the devices was confirmed to be $56.6 \mathrm{~dB}$ for the TRAUS XUS10 and $56.0 \mathrm{~dB}$ for PIEZOSURGERY touch. The two piezoelectric engines satisfied the safety standards with an operation temperature below $41^{\circ} \mathrm{C}$ after having been operated for 3 minutes. Conclusion: Except for the function key and handpiece heat emission, TRAUS XUS10 has comparable performance with PIEZOSURGERY touch. (J Dent Rehabil Appl Sci 2017;33(4):269-77)

Key words: piezoelectric engine; satisfaction; heat emission; handpiece noise

\section{Introduction}

Piezoelectric surgical devices, which started to be developed in 1998, are composed of piezoelectric handpiece, foot pedal, main unit, irrigation tube, handpiece stand and liquid solution hanger. Piezoelectric surgical devices enable more precise surgical cutting when performing external oral surgeries than drill handpieces. Piezoelectric surgical devices are also receiving attention for the ability to conduct safer surgical procedures and superior hemostasis

*Correspondence to: So-Young Choi

Assistant Professor, Department of Oral \& Maxillofacial Surgery, School of Dentistry, Kyungpook National University, 2177, Dalgubeol-daero, Jung-gu, Daegu, 41940, Republic of Korea

Tel: +82-53-600-7576, Fax: +82-53-426-5365, E-mail: dentalchoi@knu.ac.kr

Received: August 4, 2017/Last Revision: August 14, 2017/Accepted: August 21, 2017 characteristics in surgical procedure. For safe cutting through nerves, blood vessels and soft tissue, piezoelectric surgical devices operate using micro vibration at a rate of $60-200 \mathrm{~mm} / \mathrm{sec}$ to prevent damage. The increase of cutting accuracy leads to minimize the surgical site and shorten the period of post-operation healing time by leaving a clean cross section. ${ }^{1-5}$

The application fields of piezoelectric surgery include periodontology, endodontic surgery, implantology, ontological surgery, neurosurgery, orthopedic and hand surgery. ${ }^{6-8}$

Copyright@ 2017 The Korean Academy of Stomatognathic Function and Occlusion. (c) It is identical to Creative Commons Non-Commercial License. 
For the sinus elevation, which is considered when $\mathrm{RBH}$, residual bone height, is less than $6 \mathrm{~mm}$, using a rotary instrument is apt to cause sinus membrane perforations that usually lead to post-operation complications. Risk of damaging the soft tissue and blood vessel bundles is also high. The piezosurgery engine is gaining popularity as an alternate surgery technique that reduces this risks. ' It is expected that the areas where piezoelectric devices can be utilized and applied will expand with continuous growth of the implant market. ${ }^{10}$

In this research study, the user satisfaction from using two different piezosurgery engines was quantified. By comparing the user satisfaction between the globally recognized PIEZOSURGERY Touch (Mectron, Carasco, Italy) system and TRAUS XUS10 (Saeshin, Daegu, Korea), the performance of domestic piezoelectric surgery engine, TRAUS XUS10, was indirectly evaluated.

\section{Materials and Methods}

\section{User's satisfaction survey}

After testing the two implant engines against 20 dentists at the Kyungpook National University School of Dentistry in Korea from June, 15th to July, 15th of 2015, they were given a self-administered survey with 11 categories of evaluation developed in this research study to evaluate their user satisfaction. ${ }^{11}$ The performance of TRAUS XUS10 and PIEZOSURGERY touch was compared in this research study (Table 1). To exclude any influence caused by the brand and product name of the piezosurgery engine on user satisfaction during the test, blind tests were conducted without providing any information on the piezosurgery engine (Fig. 1).

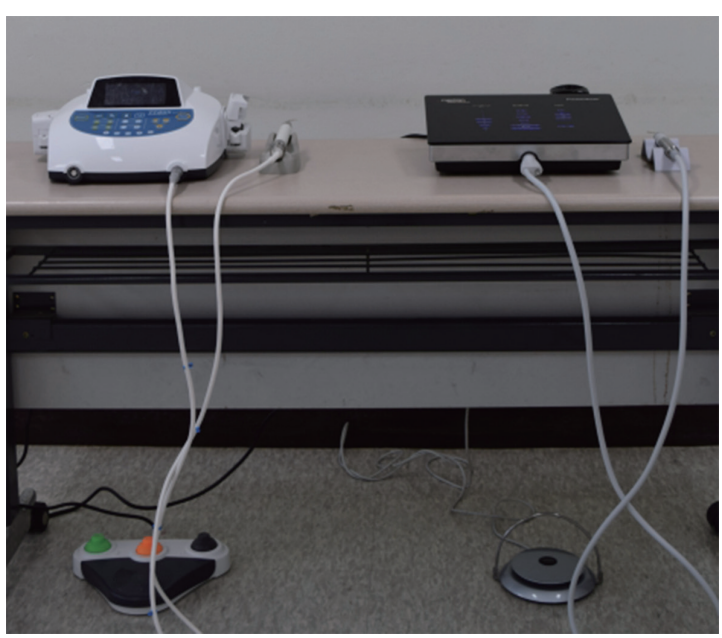

Fig. 1. TRAUS XUS10, Saeshin (Left), PIEZOSURGERY Touch (Right).

Table 1. Product specifications of the two piezosurgery engines

\begin{tabular}{|c|c|c|}
\hline & TRAUS XUS10 & PIEZOSURGERY Touch \\
\hline $\begin{array}{l}\text { Operation frequency of } \\
\text { the ultrasonic wave }\end{array}$ & $27 \pm 3 \mathrm{KH}$ & $\begin{array}{l}\text { Automatic scan } \\
\text { From } 24 \mathrm{KHz} \text { to } 36 \mathrm{KHz}\end{array}$ \\
\hline Output type of the ultrasonic wave & $\begin{array}{l}3 \text { step system } \\
(15-59 \mathrm{VA})\end{array}$ & $\begin{array}{l}\text { ENDO } \\
\text { PERIO } \\
\text { SPECIAL } \\
\text { CANCELLOUS } \\
\text { CORTICAL } \\
\text { IMPLANT } \\
\text { (values are unknown) }\end{array}$ \\
\hline Output voltage of ultrasonic wave & AC $220-240 \mathrm{~V}$ & $100-240 \mathrm{Vac} 50 / 60 \mathrm{~Hz}$ \\
\hline Maximum pump capacity & Max. $90 \pm 20 \% \mathrm{~mL}$ & $\begin{array}{l}\text { Adjustable on the touch screen: } \\
\text { ENDO/PERIO - } 7 \text { flow levels: from } 0 \text { to } 6 \\
\text { (from } 0 \text { to approximately } 75 \mathrm{~mL} / \mathrm{min} \text { ) } \\
\text { SPECIAL/CANCELLOUS/CORTICAL/IMPLANT } \\
6 \text { capacity levels: from } 1 \text { to } 6 \\
\text { (from } 8 \text { to approximately } 75 \mathrm{~mL} / \mathrm{min} \text { ) }\end{array}$ \\
\hline
\end{tabular}


11 categories of evaluation were presented in the survey. To evaluate question No.4 of the survey, cutting ability of hard tissue and adequate bone cutting properties, all clinicians were given two bone cutting tip specialized to each of the companies, and answered the question after conducting osteotomy on a pig rib specimen. ${ }^{12-15}$ The TRAUS XUS10 used Sohn's Saw (Saeshin) and the PIEZOSURGERY touch used the OT7 (Mectron) for cutting (Fig. 2).

By using the Likert 5-point scale to evaluate and convert each question on the scale of 'very dissatisfied' at 1 point, 'dissatisfied' at 2 points, 'average' at 3 points, 'satisfied' at 4 points, and 'very satisfied' at 5 points, the levels of satisfaction of the clinicians were quantified.

\section{Evaluation of the noise from the handpiece}

By applying the configuration for each of the devices that resulted in the most similar output values, the two devices were operated for 10 seconds without irrigation (Table 2). The level of noise was measured 5 times for each device using sound \& vibration solutions TSVA Ver 3.1 (Signallink, Suwon, Korea) to compare the maximum noise values.

\section{Evaluation of the heat emissions of the handpiece}

After fixing the handpiece to the Jig, Thermocoupling was attached to 3 separate positions: Position1 (P1): the tip attachment part, Position2 (P2): the part that comes into contact with the thug and index fingers when holding the handpiece, and Position3 (P3): the rest part when holding the handpiece. The handpiece was operated for 3 minutes and the heat generated from each of the parts was measured using Graphtec GL240 Midi Data Logger (GRAPHTEC, Yokohama, Japan).

\section{Statistical analysis}

A score from 'very dissatisfied' at 1 point, 'dissatisfied' at 2 points, 'average' at 3 points, 'satisfied' at 4 points, and 'very satisfied' at 5 points was assigned to each of the 11 categories designed for the survey in this research study. By applying a score distribution according to the Likert point scale, the average and standard deviation values were recorded (Table 3, 4). The results of executing Kolmogorov-Smirnov and Shapiro-Wilk to verify the normality of the data con-

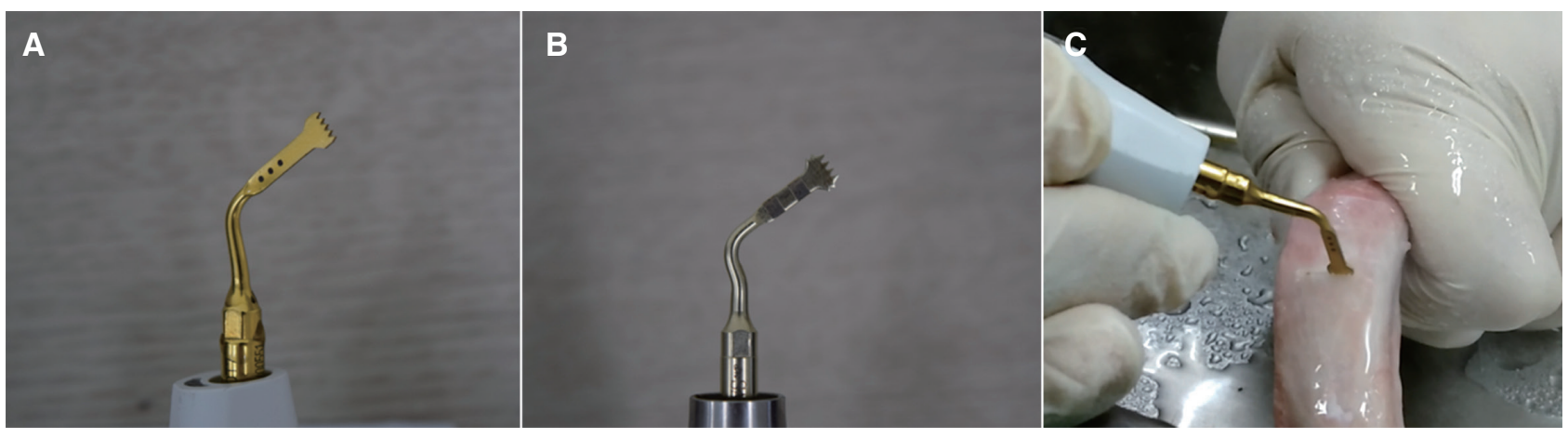

Fig. 2. Cutting the pig bone to evaluate the 'cutting ability of hard tissue, adequate bone cutting properties'. (A) OT7 (PIEZOSURGERY Touch, Mectron), (B) Sohn's Saw (TRAUS XUS10, Saeshin), (C) Pig rib sawing operation.

Table 2. Configuration values for each of the two piezosurgery engines

\begin{tabular}{ccc}
\hline & TRAUS XUS10 (Saeshin) & PIEZOSURGERY Touch (Mectron) \\
\hline Power & avg. $43.5 \mathrm{~W}$ & avg. $41 \mathrm{~W}$ \\
$(36-46 \mathrm{~W})$ & $(36-51 \mathrm{~W})$ & (configuration: Cortical) \\
& (configuration: Boost2, P-Power3) & $62 \mathrm{~mL} / \mathrm{min}(6 \mathrm{step})$ \\
\hline
\end{tabular}


firmed that both sets of data did not satisfy the conditions for normality $(P<0.05)$. To verify the statistical significance of the two products, Mann-Whitney $\mathrm{U}$ test, which is a nonparametric test, was conducted using IBM SPSS Version 20 for Windows (SPSS Inc., Chicago, USA). The results confirmed that the statistical significance was 0.05 .

\section{Results}

\section{User's satisfaction survey}

For Q7 which surveyed the noise from the irrigation pump motor, TRAUS XUS10 device was confirmed to have a statistically higher level of satisfaction when compared to PIEZOSURGERY touch. On the other hand, for Q8 which surveyed the function keys and satisfaction and for Q11 which surveyed the heat emission levels of the handpiece, the results confirmed that PIEZOSURGERY touch was superior (Table 3, 4). ${ }^{16}$ There was no statistically significant difference confirmed between the remaining category questions (Fig. 3).

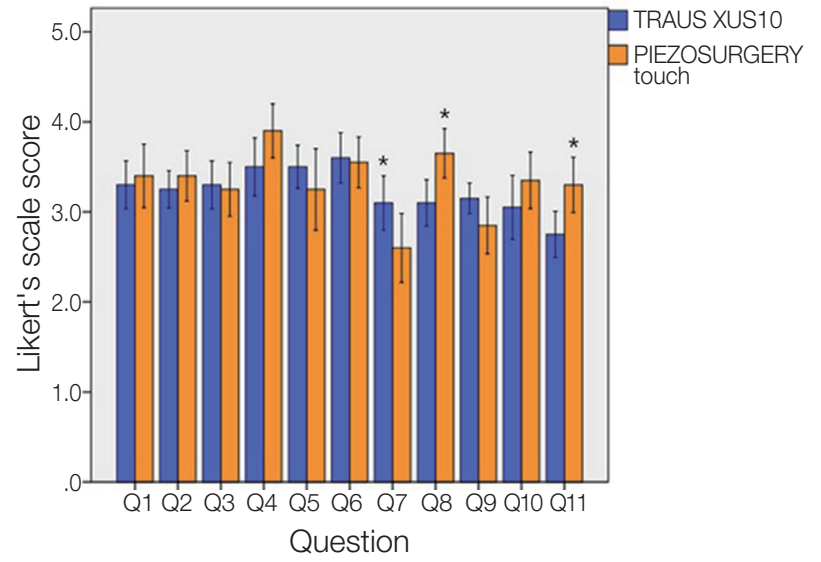

Fig. 3. Comparison for each survey question. * Statistically significant with $P<0.05$. Q1: ease of attachment and detachment of Tip, Q2: weight and balance of the ultrasonic handpiece, Q3: appropriateness of the form and shape (design) of the handpiece, Q4: cutting ability of hard tissue and adequate bone cutting properties, Q5: wide strength band, Q6: wide irrigation area, Q7: noise level of irrigation pump motor, Q8: satisfaction with regards to function keys, Q9: level of noise, Q10: amount of vibration, Q11: heat emission from handpiece.

Table 3. Likert scale point conversion for questions on clinical test satisfaction (TRAUS XUS10)

\begin{tabular}{ccccccc}
\hline \multirow{2}{*}{ Question } & Very dissatisfied & Dissatisfied & $\begin{array}{c}\mathrm{n}(\%) \\
\text { Average }\end{array}$ & Satisfied & Very Satisfied & Mean (SD) \\
\hline $1^{*}$ & $0(0)$ & $1(5)$ & $12(60)$ & $7(35)$ & $0(0)$ & $3.3(0.6)$ \\
$2^{*}$ & $0(0)$ & $0(0)$ & $15(75)$ & $5(25)$ & $0(0)$ & $3.3(0.4)$ \\
$3^{*}$ & $0(0)$ & $0(0)$ & $15(75)$ & $4(20)$ & $1(5)$ & $3.3(0.6)$ \\
$4^{*}$ & $0(0)$ & $1(5)$ & $9(45)$ & $9(45)$ & $1(5)$ & $3.5(0.7)$ \\
$5^{*}$ & $0(0)$ & $0(0)$ & $10(50)$ & $10(50)$ & $0(0)$ & $3.5(0.5)$ \\
$6^{*}$ & $0(0)$ & $1(5)$ & $6(30)$ & $13(65)$ & $0(0)$ & $3.6(0.6)$ \\
$7^{*}$ & $0(0)$ & $3(15)$ & $12(60)$ & $5(25)$ & $0(0)$ & $3.1(0.6)$ \\
$8^{*}$ & $0(0)$ & $2(10)$ & $14(70)$ & $4(20)$ & $0(0)$ & $3.1(0.6)$ \\
$9^{*}$ & $0(0)$ & $0(0)$ & $17(85)$ & $3(15)$ & $0(0)$ & $3.2(0.4)$ \\
$10^{*}$ & $1(5)$ & $1(5)$ & $15(75)$ & $2(10)$ & $1(5)$ & $3.1(0.8)$ \\
$11^{*}$ & $0(0)$ & $6(30)$ & $13(65)$ & $1(5)$ & $0(0)$ & $2.8(0.6)$ \\
\hline
\end{tabular}

$* 1$, ease of attachment and detachment of Tip; 2 , weight and balance of the ultrasonic handpiece; 3 , appropriateness of the form and shape (design) of the handpiece; 4 , cutting ability of hard tissue and adequate bone cutting properties; 5 , wide strength band; 6 , wide irrigation area; 7 , noise level of irrigation pump motor; 8 , satisfaction with regards to function keys; 9, level of noise; 10, amount of vibration; 11, heat emission from handpiece. 
Table 4. Likert scale point conversion for questions on clinical test satisfaction (PIEZOSURGERY Touch)

\begin{tabular}{|c|c|c|c|c|c|c|}
\hline \multirow{2}{*}{ Question } & \multicolumn{5}{|c|}{$\mathrm{n}(\%)$} & \multirow{2}{*}{ Mean (SD) } \\
\hline & Very dissatisfied & Dissatisfied & Average & Satisfied & Very Satisfied & \\
\hline $1 *$ & & $3(15)$ & $6(30)$ & $11(55)$ & & $3.4(0.8)$ \\
\hline $2^{*}$ & & $1(5)$ & $10(50)$ & $9(45)$ & & $3.4(0.6)$ \\
\hline $3 *$ & & $2(10)$ & $11(55)$ & $7(35)$ & & $3.3(0.6)$ \\
\hline $4^{*}$ & & & $5(25)$ & $12(60)$ & $3(15)$ & $3.9(0.6)$ \\
\hline $5^{*}$ & $1(5)$ & $2(10)$ & $10(50)$ & $5(25)$ & $2(10)$ & $3.3(1.0)$ \\
\hline $6^{*}$ & & $1(5)$ & $7(35)$ & $12(60)$ & & $3.6(0.6)$ \\
\hline $7 *$ & $1(5)$ & $9(45)$ & $7(35)$ & $3(15)$ & & $2.6(0.8)$ \\
\hline $8^{*}$ & & $1(5)$ & $5(25)$ & $14(70)$ & & $3.7(0.6)$ \\
\hline $9 *$ & & $6(30)$ & $11(55)$ & $3(15)$ & & $2.9(0.7)$ \\
\hline $10^{*}$ & & $1(5)$ & $12(60)$ & $6(30)$ & $1(5)$ & $3.4(0.7)$ \\
\hline $11 *$ & & $1(5)$ & $13(65)$ & $5(25)$ & $1(5)$ & $3.3(0.7)$ \\
\hline
\end{tabular}

$* 1$, ease of attachment and detachment of Tip; 2, weight and balance of the ultrasonic handpiece; 3 , appropriateness of the form and shape (design) of the handpiece; 4 , cutting ability of hard tissue and adequate bone cutting properties; 5 , wide strength band; 6 , wide irrigation area; 7 , noise level of irrigation pump motor; 8, satisfaction with regards to function keys; 9, level of noise; 10, amount of vibration; 11, heat emission from handpiece.
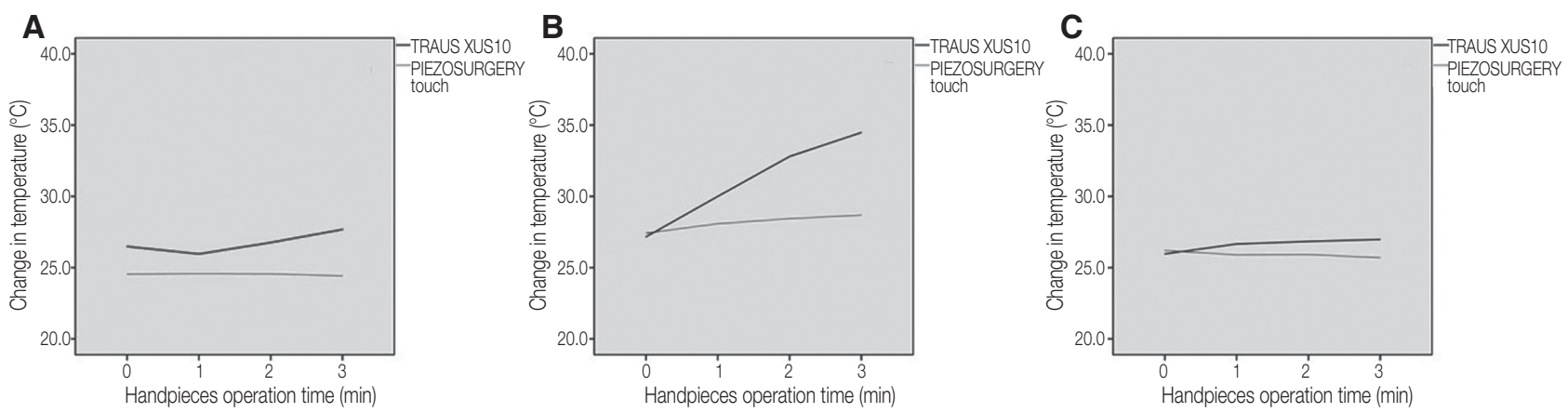

Fig. 4. The Changes in temperature according to the operation duration of the handpieces. (A) Position1: the tip attachment part, (B) Position2: the part that comes into contact with the thug and index fingers when holding the handpiece, (C) Position3: the rest part when holding the handpiece.

\section{Noise level evaluation for two handpieces}

The maximum noise level for each of the devices was confirmed to be $56.6 \mathrm{~dB}$ for the TRAUS XUS10 and $56.0 \mathrm{~dB}$ for PIEZOSURGERY touch.

\section{Heat emission level evaluation for two handpieces}

For the three measured positions, the heat emission level of the TRAUS XUS10 showed a higher level of heat during operation when compared to that of
PIEZOSURGERY touch device (Fig. 4).

According to international standards from IEC (International Electrotechnical Commission), ${ }^{17}$ the maximum permitted temperature when a device is operation is defined as $41^{\circ} \mathrm{C}$. When conducting the test for just 3 minutes according to the companies recommend with a rest of 10 minutes for the TRAUS XUS10, both TRAUS XUS10 and PIEZOSURGERY touch satisfied the safety standards with an operation temperature below $41^{\circ} \mathrm{C}$ after having been operated for 3 minutes. 


\section{Discussion}

The objective of this research study was to measure the user satisfaction between two different piezoelectric engines and conduct a comparative evaluation of performance between the product developed in Korea and a piezoelectric engine that has been certified overseas. The clinicians evaluated to the piezoelectric engines that had been setup in the same room. For Q4, which asked about the cutting ability of hard tissue and adequate bone cutting properties, while PIEZOSURGERY touch showed a high level of user satisfaction, the results also were confirmed that there was no statistical significance. When conducting cutting operations in this research, each company's specialized tip for each engine was used. It has been known that the overall resonant frequencies change depending on the shape and size of the surgical tip, and the center frequency changes depending on the differences in the pressure applied during a surgical procedure. Therefore, it is not possible to totally eliminate the influences from the differences in the tip designs of the two piezoelectric engines and the pressure applied when operating the two piezoelectric engines, which is a factor dependent upon the clinician. On that point of view, we used the company's recommended tip to minimize the predictable errors. For Q7, which asked about the noise level of irrigation pump motor, TRAUS XUS10 was confirmed to have a statistically significantly high level of user satisfaction. In general ultrasonic bone procedure, headpieces used in dental practices must operate at low frequency ranges in order to perform at a high output level. However, once the frequency drops as low as $20 \mathrm{kHz}$, which is in the audible frequency range and this causes difficulties in using the device due to noise. That is why these devices use $30-40$ $\mathrm{kHz}$ frequency range. ${ }^{18}$ The frequency range used for the ultrasonic function of TRAUS XUS10 handpiece was $27 \pm 3 \mathrm{kHz}$, which falls in an appropriate frequency range to be used in clinical studies. On the other hand, Piezosurgery has $24 \mathrm{kHz}-36 \mathrm{kHz}$ frequency range. Kramer et al. ${ }^{19}$ claim it shows a similar level of sound pressure level (SPL), com- pared to when conducting conventional osteotomies. Even though TRAUS XUS10 showed a comparatively higher handpiece noise level, when operating this device together with irrigation pumps, TRAUS XUS10 gained more satisfaction from the users. That is considered to be because the irrigation pump noise of the PIEZOSURGERY touch was higher than that of the TRAUS XUS10. If mechanical technique of the each piezoelectric engine is informed, further research on the cause and result of the data will be explained better, however, it is not allowed now. Letho etc. ${ }^{20}$ reported that people who are relatively susceptible to hearing damage have the risk to incur gradual hearing damage even from dental drills. The sound radiated during dental procedures has high level of noise above $70 \mathrm{~dB}$ (A) and high frequency of $4 \mathrm{kHz}$. That is why there is a clinical demand for technology to reduce this risk of hearing damage. Technology that can reduce noise will be recognized as a one of the important factors on the level of user satisfaction when using a device. ${ }^{21,22}$

The range of the level of sound generated by dental devices when treating patients such as scaling, tooth preparation etc. and doing non-medical examination like idling is between $67.7-78.3 \mathrm{~dB}(\mathrm{~A})$. For patients who show a shocked or uncomfortable response when exposed to sharp noise during treatment, the influence of the noise radiated from the devices cannot be ignored in terms of patient cooperation. The ISO, International Organization for Standardization, regulates noise level standards for a room and suggests working place to keep noise level at NRN (Noise Reduction Number) 60 - 70 dB (A). Dental devices have a necessity to be developed to meet the requirement. $^{21}$

For Q8, function keys and satisfaction, and for Q11, heat emission levels of the handpiece, PIEZOSURGERY touch had higher level of user satisfaction. On the basis of the fact that both products provide several function keys that enable various output values and irrigation rate ranges to be configured, there could be another factor to make the survey result divergent. One possible factor is device design. PIEZOSURGERY touch is equipped with an LED touch screen unlike the button style of the 
TRAUS XUS10. Considering a design only, the two devices show a significant difference. These elements are expected to effect on the satisfaction level of the devices that cater to the market trends where consumers prefer touch screens in various devices. Add to this, PIEZOSURGERY touch has more subdivided function keys which allow the users to setup the mode they need more sophisticated. While TRAUS XUS10 has just several keys with roughly categorized, it does not mean that it is not acceptable for clinical usage. Well-subdivided keys allow more customized set-up, though, excessive division can result in time consuming for changing set-up during operation. Roughly dived function keys have strong point on that point of view; however, they have a risk to give inadequate operation condition as well. Considering these weak and strong points, the users favor will also affect on the satisfaction finally. For Q11, the level of satisfaction for TRAUS XUS10 was low and this can be caused by the differences in the structure of the handpiece that cannot insulate heat as well as the handpiece of PIEZOSURGERY touch. The two devices were confirmed to have an especially higher increase in temperature near the position P2 where piezoelectric elements are placed. TRAUS XUS10 showed a temperature increase in the positions $\mathrm{P} 1$ and P3, which can be assumed to be caused by the design of the handpiece of TRAUS XUS10, which is not as good at insulating heat as much as the handpiece of PIEZOSURGERY touch does. Because the heat generated by the piezoelectric elements' vibration is transferred to the whole body of the handpiece, the technological know-how to insulate this heat can cause the mentioned perceived differences in heat emission. In this study, the measurement of emitted heat was limited to the heat transferred to the clinician. If future research can include examination on the increase in temperature of the tissue that contacts with the end of the surgical tip during surgery, it will be possible to investigate the overall level of user satisfaction for the devices based on rapid post-surgery recovery and a decrease in medical complication from the surgical procedure. ${ }^{23}$

Even though TRAUS XUS10 needs to be im- proved slightly in terms of function key and the amount of heat emitted through the handpiece, it appears that this device has a comparable level of satisfaction in most of the other evaluation categories when compared to PIEZOSURGERY touch. As the first device in Korea that combines an implant motor and an ultrasonic device, TRAUS XUS10 is expected to be competitive with PIEZOSURGERY touch with accompanied by improvement on performance and sensitive reaction to users' opinions. In addition, when an implant surgery requires both an ultrasonic treatment device and implant drill device, all in one system of TRAUS XUS10 decreases the movement range of the operator by installing only one device. Than can decrease clinician's fatigue and enhances the efficiency of surgery.

\section{Conclusions}

TRAUS XUS10 showed higher user satisfaction on the noise level of irrigation pump motor than PIEZOSURGERY touch. While, PIEZOSURGERY touch had higher satisfaction with regards to function key and heat emission from handpiece compared to TRAUS XUS10. TRAUS XUS10 has comparable satisfaction with that of PIEZOSURGERY touch in other survey lists. When further improvement based on the clinicians' evaluation and its lower market price meets together, TRAUS XUS10 is considered to have enough potential competitiveness in peizosurgery market.

\section{Acknowledgements}

This work was supported by the Ministry of Trade, Industry and Energy of the Republic of Korea and Daegu Institute for Regional Program Evaluation and Daegu Technopark (Regional Key Industries Promotion Project).

\section{ORCID}

Hyun-Mi Lim https://orcid.org/0000-0001-9700-5673

Kyu-Bok Lee https://orcid.org/0000-0002-1838-7229

Wan-Sun Lee https://orcid.org/0000-0002-4410-5854 
So-Young Choi https://orcid.org/0000-0002-2563-3539

\section{References}

1. Stübinger S, Kuttenberger J, Filippi A, Sader R, Zeilhofer HF. Intraoral piezosurgery: preliminary results of a new technique. J Oral Maxillofac Surg 2005;63:1283-7.

2. Blus C, Szmukler-Moncler S, Salama M, Salama H, Garber D. Sinus bone grafting procedures using ultrasonic bone surgery: 5-year experience. Int J Periodontics Restorative Dent 2008;28:221-9.

3. Robiony M, Polini F, Costa F, Vercellotti T, Politi M. Piezoelectric bone cutting in multipiece maxillary osteotomies. J Oral Maxillofac Surg 2004;62:75961.

4. Ma L, Stübinger S, Liu XL, Schneider UA, Lang NP. Healing of osteotomy sites applying either piezosurgery or two conventional saw blades: a pilot study in rabbits. Int Orthop 2013;37:1597-603.

5. Eggers G, Klein J, Blank J, Hassfeld S. Piezosurgery: an ultrasound device for cutting bone and its use and limitations in maxillofacial surgery. $\mathrm{Br} \mathrm{J}$ Oral Maxillofac Surg 2004;42:451-3.

6. Labanca M, Azzola F, Vinci R, Rodella LF. Piezoelectric surgery: twenty years of use. Br J Oral Maxillofac Surg 2008;46:265-9.

7. Seshan H, Konuganti K, Zope S. Piezosurgery in periodontology and oral implantology. J Indian Soc Periodontol 2009;13:155-6.

8. Vercellotti T, Dellepiane M, Mora R, Salami A. Piezoelectric bone surgery in otosclerosis. Acta Otolaryngol 2007;127:932-7.

9. Jensen OT, Shulman LB, Block MS, Iacono VJ. Report of the Sinus Consensus Conference of 1996. Int J Oral Maxillofac Implants 1998;13 Suppl:11-45.

10. Seshan H, Konuganti K, Zope S. Piezosurgery in periodontology and oral implantology. J Indian Soc Periodontol 2009;13:155-6.

11. Lee DH, Lee KB. The comparative study of user satisfaction on various implant engine system. J Dent Rehabil Appl Sci 2014;30:9-15.

12. Pearce AI, Richards RG, Milz S, Schneider E, Pearce SG. Animal models for implant biomaterial research in bone: a review. Eur Cell Mater 2007;13:1-10.

13. An YH, Freidman RJ. Animal models in orthopaedic research. Boca Raton; CRC Press; 1998. p. 3957.

14. Buser D, Schenk RK, Steinemann S, Fiorellini JP, Fox $\mathrm{CH}$, Stich $\mathrm{H}$. Influence of surface characteristics on bone integration of titanium implants. A histomorphometric study in miniature pigs. J Biomed Mater Res 1991;25:889-902.

15. Sun C, Huang G, Christensen FB, Dalstra M, Overgaard S, Bünger C. Mechanical and histological analysis of bone-pedicle screw interface in vivo: titanium versus stainless steel. Chin Med J (Engl) 1999;112:456-60.

16. Davies AR, Ware JE Jr. Measuring patient satisfaction with dental care. Soc Sci Med A 1981;15:75160.

17. IECEE. International Electrotechnical Commission. Available from: http://www.iec.ch/ search $/$ ?q $=$ Applied $\% 20$ parts $\% 20$ not $\% 20$ intended $\% 20$ to $\% 20$ supply $\% 20$ heat $\% 20$ to $\% 20$ a $\% 20$ patient' (updated 2017 Aug 14).

18. Lee JH, Oh JM, Hong Y, Kim S, Paik J, Lee YJ, Lee JB, Lee SD. Design and evaluation of ultrasonic bone surgical instruments for dental application. J Korean Inst Electr Electron Mater Eng 2012;25:990-5.

19. Kramer FJ, Bornitz M, Zahnert T, Schliephake H. Can piezoelectric ultrasound osteotomies result in serious noise trauma? Int J Oral Maxillofac Surg 2015;44:1355-61.

20. Lehto TU, Laurikainen ET, Aitasalo KJ, Pietilä TJ, Helenius HY, Johansson R. Hearing of dentists in the long run: a 15-year follow-up study. Community Dent Oral Epidemiol 1989;17:207-11.

21. Ji DH, Choi MS. Characteristics of noise radiated at dental clinic. J Korean Soc Environ Eng 2009;31: 1123-8.

22. Lee JS, Han YS, Cho YS. The noise level assessment of dental equipment. J Dent Hyg Sci 2015;15; 603-11.

23. Walmsley AD. Potential hazards of the dental ultrasonic descaler. Ultrasound Med Biol 1988;14:15-20. 


\section{두가지 피에조 엔진의 사용자 만족도 비교}

\section{임현미 ${ }^{1,2,3}$, 이규복 ${ }^{2,3}$, 이완선 ${ }^{2}$, 최소영 ${ }^{4 *}$}

${ }^{1}$ 경북대학교 대학원 치의학과

${ }^{2}$ 경북대학교 첨단치과의료기기개발연구소

${ }^{3}$ 경북대학교 치과대학 치과보철학교실

${ }^{4}$ 경북대학교 치과대학 구강악안면외과학교실

목적: 치과의사의 사용 만족도 비교를 통해 두 가지 피에조 엔진의 성능을 비교평가 하고자 한다.

연구 재료 및 방법: 본 연구에서는 두 가지의 피에조 엔진을 평가하였다:TRAUS XUS10 (Saeshin), PIEZOSURGERY touch (Mectron). 20명의 치과의사가 11개 평가항목에 답하였고, 평가결과는 Likert의 5점 척도를 적용하여 수치화하였 다. 핸드피스 소음평가는 10 초 동안 5 회 측정하여 최고소음을 비교하였다. 핸드피스 발열평가는 세 부위에서 3 분동안의 발열량을 측정하였다.

결과: 평가항목 중 ‘주수펌프 모터의 소음’에서 TRAUS XUS10이 PIEZOSURGERY touch보다 유의하게 만족도가 높았다. 반면, '기능key의 만족도'와 '핸드피스 발열정도'는 PIEZOSURGERY touch가 더 우수했다. 소음 최대값은 TRAUS XUS10이 $56.6 \mathrm{~dB}$, PIEZOSURGERY touch는 $56.0 \mathrm{~dB}$ 였다. 두 기기 모두 3 분 작동 후 $41^{\circ} \mathrm{C}$ 미만의 열을 발생 시킴으로써 안전기준을 만족하였다.

결론: TRAUS XUS10는 '기능 key' 및 '핸드피스 발열정도'에서 약간의 개선을 한다면 그 외 대부분의 평가항목에서는 PIEZOSURGERY touch과 견줄만한 성능을 보인다.

(구강회복응용과학지 2017;33(4):269-77)

주요어: 피에조 엔진; 만족도; 열발생; 핸드피스 소음

*교신저자: 최소영

(41940)대구광역시 중구 달구벌대로 2177 경북대학교 치과대학 구강악안면외과

Tel: 053-600-7576 | Fax: 053-426-5365 | E-mail: dentalchoi@knu. ac. kr

접수일: 2017년 8월 4일 | 수정일: 2017년 8월 14일 | 채택일: 2017년 8월 21일 